情報地質 (12)，143～150， 1987

\title{
日本の脊椎動物化石標本データーベースJAFOV の現況之将来計画
}

\author{
山本 嘉一郎*・西脇 二一**・亀井 節夫**
}

\section{1.はじめに}

筆者らは昭和56年以来日本の脊椎動物化石標本 データベース JAFOV の構築を続けている。これ までに京都大学収蔵標本についてのデータ入力を 終了し、日本の長鼻類標本のデータについては過 半数の入力を終了した。JAFOVのシステムにつ いては既に報告しているので（山本ほか，1982， 1986; 龟井ほか, 1986; Nishiwaki et al, 1983; Nishiwaki，1986）、本報告では入力デー夕の具 体的内容について紹介するとともに、今後のデー 夕入力計画とシステム改良計画について解説する。 本論に先立ち JAFOVのデータ収集にご協力頂 いている長鼻類総研および海生哺乳類総研の各位、 及びデータ入力にご協力頂いている京都大学古生 物学研究グループの各位に心より感謝申し上げる。

なお本論は、昭和62年 6 月 12 日大阪工業大学で 行なわれた第二回情報地質研究発表会および昭和 62年 6 月 20 日福井県立博物館で行なわれた日本古 生物学会第136回例会において発表した内容に加 筆したものである。両者における各位のご討論に 感謝申し上げる。

\section{2. データベースの内容}

現在 JAFOV に入力されている標本は京都大学 所蔵のものと、長鼻類総研によって収集された長 鼻類関係のものである。そのため地域的にも、夕

*光華女子短期大学情報処理研究室

$* *$ 京都大学理学部地質学鉱物学教室
クサ的にも、かなりの偏りがあるが、現状をその まま紹介してみたい。

まず標本の産出国別にみてみると(第 1 表)、日 本とイランが圧倒的に多い。その他は、中国と韓 国がそれぞれ 6 標本で、それ以外の国は 1 標本づ つである。イランが多いのは、たまたま京都大学 の調査隊が採集した標本が多数あったからである。 なお、インド洋とあるのは現生の鮫の標本である。 タクサ別にみてみると(第 2 表) Proboscidea と Perissodactyla とが圧倒的に多い。その他では、

第 1 表 JAFOVにおける国別標本数

\begin{tabular}{lrllr} 
Country & Specimen & & Country & Specimen \\
\cline { 5 - 5 } CHINA & 6 & GERMANY & 1 \\
INDIAN OCEAN & 1 & IRAN & 89 \\
JAPAN & 92 & KOREA & 6 \\
TAIWAN & 1 & USA & 1 \\
USSR & 1 & &
\end{tabular}

第 2 表 JAFOVにおけるタクサ別標本数

$\begin{array}{rlrr}\text { Taxon Code } & & \text { Order } & \text { Specimen } \\ 52000 & & \text { LAMNIFORMES } & 2 \\ 63200 & & \text { CLUPEIFORMES } & 3 \\ 80300 & & \text { TESTUDINATA } & 1 \\ 101700 & & \text { CARNIVORA } & 1 \\ 102300 & & \text { PROBOSCIDEA } & 91 \\ 102500 & & \text { DESMOSTYLIA } & 7 \\ 103100 & & \text { PERISSODACTYLA } & 92 \\ 103600 & & \text { CETACEA } & 1\end{array}$


山本嘉一郎・西脇二一・亀井節夫

第 3 表 JAFOVにおける年代別標本数

\begin{tabular}{lr}
\multicolumn{1}{c}{ Period } & Specimen \\
\cline { 2 - 2 } JURASSIC & 3 \\
PALEOGENE & 2 \\
NEOGENE & 108 \\
NEOGENE? & 3 \\
QUATERNARY & 65 \\
QUATERNARY? & 4 \\
RECENT & 1
\end{tabular}

第 4 表 国内産標本の都道府県別標本数

\begin{tabular}{|c|c|c|c|}
\hline 都道府県 & 標本数 & 都道府県 & 標本数 \\
\hline 千葉 & 6 & 愛媛 & 1 \\
\hline 福岡 & 6 & 岐阜 & 1 \\
\hline 群馬 & 1 & 北海道 & 17 \\
\hline 兵庫 & 5 & 茨城 & 1 \\
\hline 石川 & 2 & 岩手 & 1 \\
\hline 香川 & 1 & 神奈川 & 1 \\
\hline 熊本 & 2 & 宮城 & 1 \\
\hline 宮崎 & 1 & 長野 & 5 \\
\hline 長崎 & 8 & 大分 & 5 \\
\hline 岡山 & 1 & 沖縄 & 5 \\
\hline 大阪 & 3 & 滋賀 & 2 \\
\hline 島根 & 2 & 静岡 & 3 \\
\hline 東京 & 2 & 富山 & 2 \\
\hline 山梨 & 1 & & \\
\hline
\end{tabular}

Desmostylia が 7 標本ある。他はいずれも数標本 のみである。長鼻類の標本が多いのは長鼻類総研 によって収集された標本が入力されているからで ある。また Perissodactyla の標本が多いのは前 述の京都大学の調査隊がイランで収集した標本の 大部分がこのタクサであったことによるものであっ て、不自然なタクサ分布となっている。

産出年代別に見てみると(第 3 表)、新第三紀が もっとも多く、次いで第四紀となっている。化石 の発見率は新しい時代のものほど高いので、古第
第 5 表 国内産標本の 20 万分の 1 地形図別標本数
20万分の 1

\begin{tabular}{|c|c|c|c|}
\hline 地形図 & 標本数 & 地形図 & 標本数 \\
\hline 千葉 & 2 & 福岡 & 4 \\
\hline 浜松 & 1 & 広尾 & 3 \\
\hline 一関 & 1 & 飯田 & 1 \\
\hline 金沢 & 2 & 北見 & 1 \\
\hline 甲府 & 1 & 久遠 & 1 \\
\hline 熊本 & 2 & 釧路 & 1 \\
\hline 京都、大阪 & 2 & 松江 & 1 \\
\hline 松山 & 1 & 宮古島 & 4 \\
\hline 長野 & 3 & 名古屋 & 1 \\
\hline 那覇 & 1 & 延岡 & 1 \\
\hline 野辺地 & 1 & 大分 & 5 \\
\hline 留萌 & 1 & 札幌 & 9 \\
\hline 仙台 & 1 & 大社 & 1 \\
\hline 高梁 & 1 & 高山 & 2 \\
\hline 徳島 & 6 & 東京 & 3 \\
\hline 富山 & 1 & 豊橋 & 3 \\
\hline 宇都宮 & 1. & 和歌山 & 2 \\
\hline 八代 & 10 & 横須賀 & 5 \\
\hline
\end{tabular}

三紀以前のものが少ないのは当然であるが、新第 三紀のものとしては前述のイランの標本が含まれ ていることは注意しなくてはならない。近年白亜 紀の恐竜なども多く産出しており、将来的にはよ り古い時代の標本の比率が高くなることも期待さ れる。

日本国内産の標本の都道府県別標本数をみてみ ると(第 4 表)、北海道、九州、および沖縄が多く なっている。これは長鼻類総研によって収集され たデータのうち、上記三地区のものが優先的に入 力されていることによるもので、長鼻類関係の全 てのデーターが入力されれば修正されることが期 待される。

日本国内産の標本の二十万分の一地形図別の標 本数(第 5 表)についても同様な地域的偏りがみら 
日本の脊椎動物化石標本データーベースJAFOVの現況と将来計画

第 6 表 国内産標本の産出層準別標本数

\begin{tabular}{|c|c|c|c|}
\hline 層群 & 標本数 & 層群 & 標本数 \\
\hline 厚内 & 1 & 備北 & 1 \\
\hline 古琵琶湖 & 1 & 口之津 & 9 \\
\hline 口之津？ & 1 & 瑞浪 & 1 \\
\hline 大分 & 5 & 大阪 & 4 \\
\hline 琉球 & 1 & 島後 & 2 \\
\hline 下総 & 1 & 冨草 & 1 \\
\hline 八女 & 2 & 八尾 & 1 \\
\hline
\end{tabular}

れる。

日本国内産の標本の産出層準別の標本数として 層群別の標本数をみてみると(第 6 表)、口の津層 群、大分層群および大阪層群からの産出標本数が 多い。このうち前二者は長鼻類総研のデーターに よるものであり、最後者は京都大学収蔵標本によ るあのである。なお、国内産標本のうち産出層準 が層群単位で入力されているものは約 3 割しかな く、データベースとしては不満足である。

このように現在の JAFOVに入力されているデー 夕には多くの偏りや不十分な点がある。これらは 今後のデータの追加扰よび修正によって改良され ていか妆ばなない。

\section{3. 入力計画}

現在進めている長鼻類関係のデータ入力は今年 中に完了させるべく作業を進めている。また、海 生哺乳類については、海生哺乳類総研のメンバー によってデータの収集とデータシートへの記入が 進められており、これが届き次第入力を行なうこ ととしている。

なお日本の洞窟堆積物中の䎋㐘類化石について は一万を越える標本の記載が進められており、そ の担当研究者がこのデータベースに入力して頂け ることとなっている。
今後の入力データの搪張の方向として次の三つ を考えている。

第一はこれまで長鼻類および海生哺乳類につい て行なったように、特定のタクサについての研究 活動の一環としてデータシートへの記入を行なっ てもらえるように働きかけていくことである。

第二はこれまでの記載標本を中心とするデー夕 の収集に加えて、未記載標本についてもデー夕を 収集することである。この場合、当該標本の研究 の支障にならないように、動物命名規約等に抵触 しない範囲内のデータを入力することとする。

第三はこれまでも行なってきたことであるが、 原標本に加えて模型標本についても積極的にデー 夕を収集することである。模型標本は比較研究に とって極めて重要であるが、その所在については 原標本についてよりも知られていないことが多い ので、データベースにより情報を提供することは 極めて意義あることである。

我々はこのような方向加ら JAFOV のレベルアッ プに努め、現在のテスト版の段階から実用版の段 階へ早期に移行させたいと考えている。これに必 要な研究者各位の理解とご協力を切に希望するす のである。

\section{4. システム改良計画}

システム改良計画については、パソコンによる 利用を可能にすること、および、デー夕入力の負 担を軽減することの二点を検討している。

前者は、データベース本体は大型計算機上に構 築し、通信ネットワークを全国各地から直接利用 するという基本形態はそのままにするとしても、 パソコンが広く普及したという現状では、検索作 業についてはパソコンでも利用できるようにして いくことが必要となってきたということである。 その際、パソコンの機種によるシステムの制約を どのようにクリヤするか、また、日本語を導入し 
山本嘉一郎・西脇二一・亀井節夫

た場合の国際性の欠落をどのように回避するか、 などが大きな問題となる。この点については現在 テスト版を作成し、具体的な検討を行なっている （山本ほか、1986）。

後者はデータベースをスムーズに構築するため に大切なことで、特にボランティアにより構筑さ れるデータベースにとっては重要な問題である。 現在 JAFOV のデータ入力は研究者によるデータ シートへの記入、データベース構想グループによ るデー夕のチェックと補充、拈よびデータベース 構築グルーブによる入力と交換の三段階で進如ら れている。この作業を正確かつ効率的に行なえる ようにするため、データシートの書式の改訂を行な うと共に、データ・チェックのため入力データをデー タシート形式で出力するプログラムを作成した。

今回の改訂のおもな目的は以下の四点である。

1. データ項目を整理して研究者によるデータシー トへの記入の負担を軽減する。

2.デー夕の記入漏れを少なくし、構想グループ によるデータ補充の作業量を軽減する。

3.データ入力の書式と対応させ、構築グループ によるデー夕入力および交換の作業の効率化 を計る。

4. データシートの書式とデータベースの構造と をできるだけ調和させて、研究者がデータベー スのイメージを持てるようにする。

具体的には以下の六点の改訂を行なった。

1.デー夕項目を必須項目、追加項目、およびこ れらから補充できる項目の三種類に区分する。

2.データベースにおけるデー夕構造と対応した 形で全てのデータ項目をデータシート上に表 示する。

3. データシート上でデータ項目を区分し、研究 者が優先的に記入すべき項目を明示する。

4. 英文化を容易にするため必要に応じてフリガ ナまたは英文を併記できるようにする。

5.コード化されている項目ではコードと值とを 併記して、コード表なしで記入および入力で
きるようにする。

6. データシート記入のための留意点をデータシー トの末尾に表示する。

今回改訂された新しいデータシートを第 1 図に 示す。

データベースの構築を進めるにはデータの入力 と共にチェックが必要である。これまでこの作業 は、データベースの検索機能を利用して行なうと 共に、入力データのダンプリストおよびデータベー スからの出力を研究者に送って校正してもらうこ とにより行なってきたが、これでは入力エラーお よびデータ欠落の発見効率が悪く、充分なチェッ クができなかった。そこで入力データをデータシー トと類似の書式で印刷することにより、データチェ ックの作業の効率を改善させることとした。プロ グラムはFORTRAN で書かれた極めて簡単なむ ので、原則として一つの標本について LP 用紙一 枚に印刷される。この場合、必須項目の欠落など の指摘が容易となるので、今後はこの出力を各研 究者に送って校正してもらうこととしている。

データチェック用出力例を第 2 図に示す。

\section{5. おわりに}

本論で紹介したようにJAFOV の現状はまだテ スト版の段階にあり、実際の研究において利用さ れるだけの標本が入力された実用版を提供するに はまだまだ多くの問題がある。特に入力すべき標 本についての情報を収集するには多くの研究者の 理解之協力が必要であり、そのためには各研究者 にかかる負担を出来るだけ少なくするようにシス テムを改善していかねばならない。本論で述べた データシートの書式の改訂やパーソナルコンピュ ターによる利用はこの面にも貢献できるものと考 えている。

最後に今後のデータベース構築作業への各位の ご協力を重ねてお願いする。 
日本の脊椎動物化石標本データーベースJAFOVの現況と将来計画

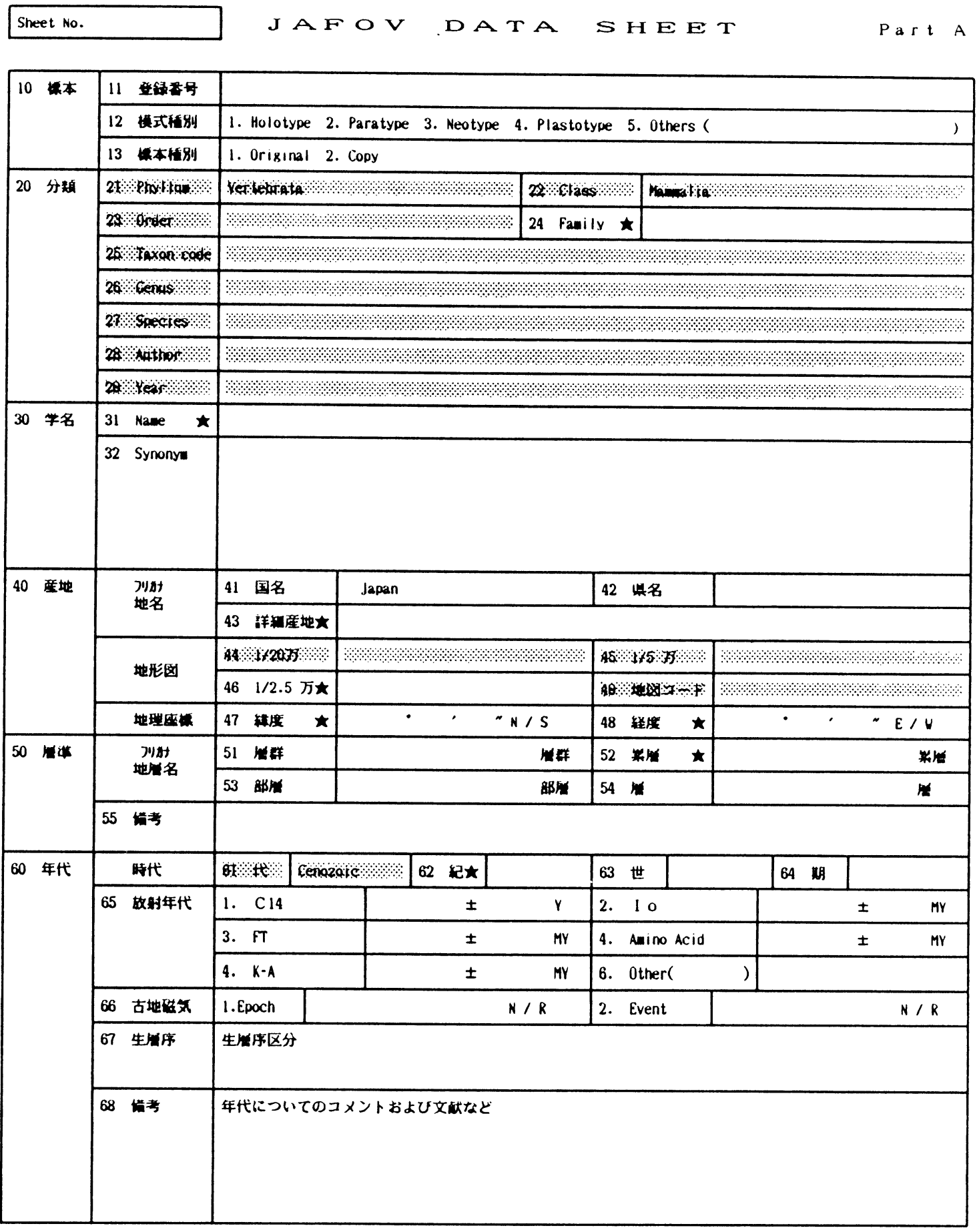

第 1 図 改訂されたJAFOV データシート 
山本嘉一郎・西脇二一・亀井節夫

Shet No. JAFOV DAT A SHEET Part B

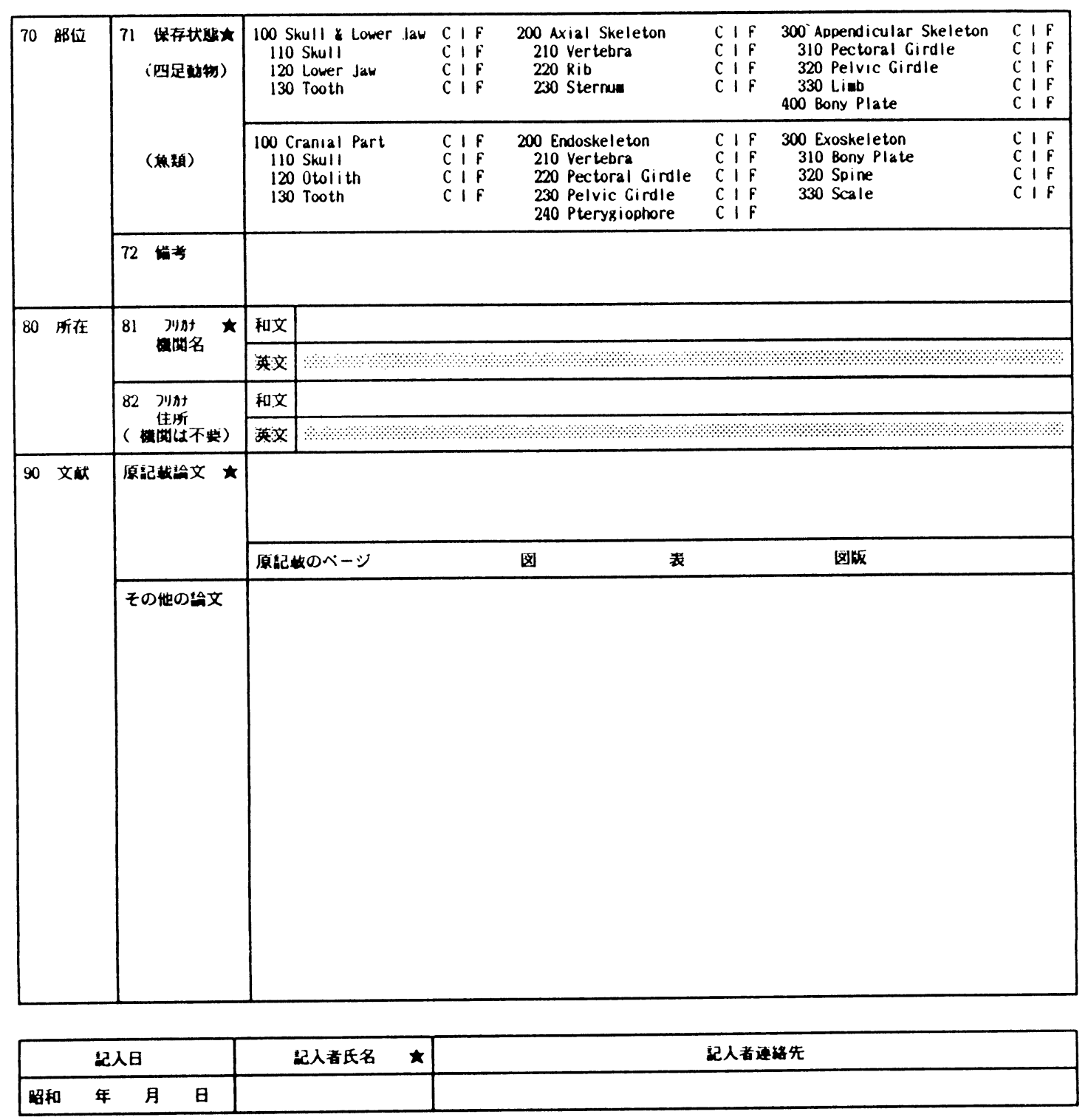

๘人の手引を

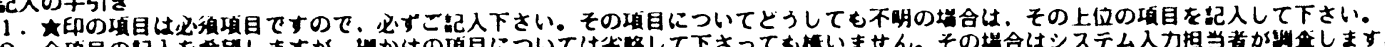

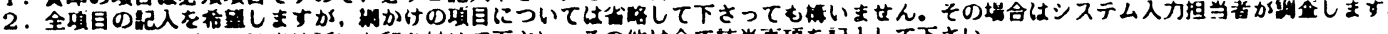

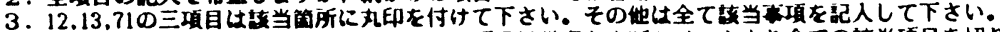

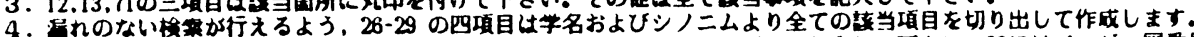

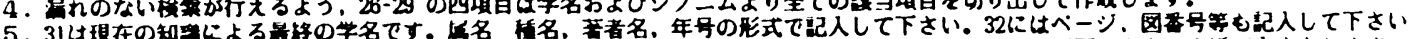

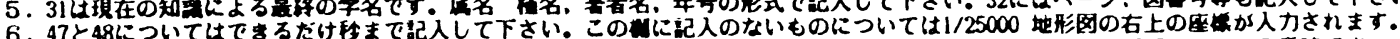

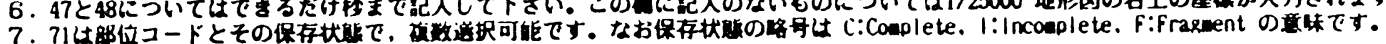

第1図（続き） 
日本の脊椎動物化石標本データーベースJAFOVの現況と将来計画

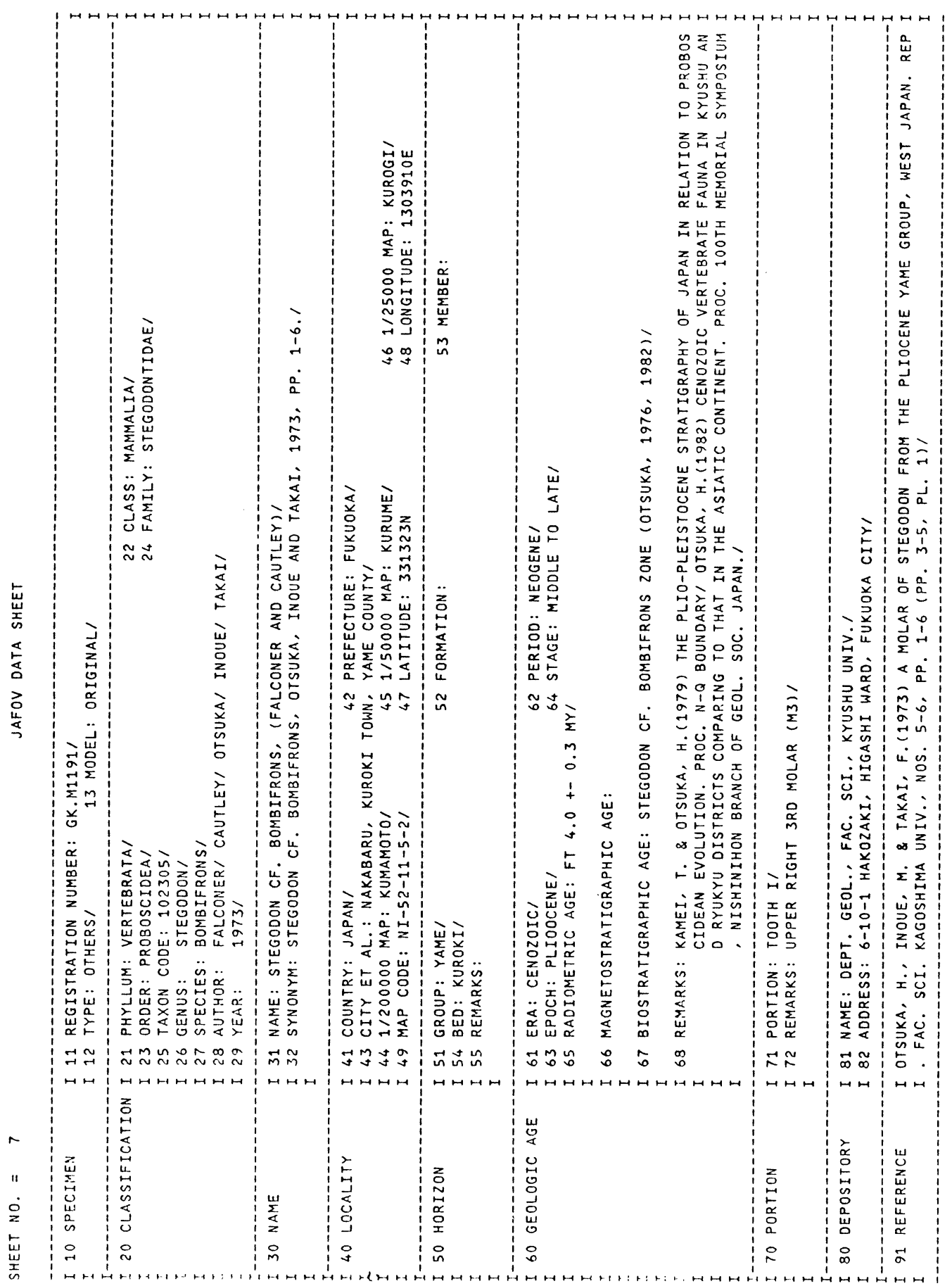

第2図 データ検定用データシート形式出力例 


\title{
山本嘉一郎・西脇二一・亀井節夫
}

\section{引用文献}

\author{
亀井節夫・山本嘉一郎・西脇二一(1986)日本にあ \\ る脊椎動物化石の標本データベース, JAFOV. \\ 京大大型計算機センター広報, vol. 19, No. 4, \\ pp. $260-268$. \\ Nishiwaki, N. (1986) Database on fossil \\ specimens deposited in Japan. in F. P. \\ Shelly ed. Proc. 3rd Intern. Conf. Geosci. \\ Inform., Adelaide, Austlalian Mineral \\ Found., vol. 1, pp. 62-70. \\ Nishiwaki, N., Yamamoto, K. and Kamei, T.
}

(1983) JAFOV - Database on the Japanese fossil vertebrates. in P. S. Glaeser, ed. Data for Science and Technology (Proc. 8th Intern. CODATA Conf.), NorthHolland Pub. Co., pp. 75-80.

山本嘉一郎・亀井節夫・西脇二一（1986）在日本 脊椎動物化石標本データーベース JAFOVの パーソナルコンピューター化, 光華女子短大研 究紀要, vol. 24, pp. 81-104.

山本嘉一郎・西脇二一・亀井節夫 (1982) 脊椎動 物化石の標本データーベース JAFOV (1). 情 報地質, No. 7 , pp. 21-30.

Present State and Future Plan of the JAFOV:

Database on Fossil Vertebrate Specimens Deposited in Japan

YAMAMOTO, Kaichiro*, NISHIWAKI, Niichi** and KAMEI, Tadao**

* Institute of Information Processing, Kouka Women Junior College, Japan 38, Nishikyougoku Kadono-cho, Ukyou-ku Kyoto, 615

** Department of Geology and Mineralogy, Faculty of Science, Kyoto University, Kitashirakawa Oiwake-cho Sakyo-ku. Kyoto, 606, Japan

\begin{abstract}
The JAFOV contains data on fossil specimens deposited in the Kyoto University and those of Proboscidea being kept in museams and institues. It is a prototype database and is not yet sufficient to be used for actual researches of vertebrate paleontology since only restricted specimens are included. It is now planned to input data moreover on fossil marine mammals, Quaternary rodents, unpublished specimens and models for reference in the near future. The format of data sheet was updated, and a program was developed to decode data in the database into the data sheet format for examining input data.
\end{abstract}

